\title{
Studies on Mean Performance for Yield and its Contributing Traits in Cauliflower (Brassica oleracea L. var. botrytis L.) Under Mid Hill Conditions of North-Western Himalayas
}

\author{
Surbhi Sharma*, Yudhvir Singh, Simran Sharma, \\ Vishalakshi and Bhallan Singh Sekhon
}
Department of Vegetable Science and Floriculture, College of Agriculture, CSK HPKV, Palampur, 176062 (H.P.), India

*Corresponding author

\section{A B S T R A C T}

\begin{tabular}{|l|}
\hline K e y w o r d s \\
Cauliflower, \\
$\begin{array}{l}\text { Evaluation, Harvest } \\
\text { index, Hybrids, } \\
\text { Yield }\end{array}$ \\
\hline Article Info \\
\hline $\begin{array}{l}\text { Accepted: } \\
\text { 26 January 2018 } \\
\text { Available Online: } \\
\text { 10 February } 2018\end{array}$ \\
\hline
\end{tabular}

\section{Introduction}

Cauliflower (Brassica oleracea L. var. botrytis L., $2 \mathrm{n}=2 \mathrm{x}=18$ ) is one of the most popular Brassica vegetables cultivated worldwide in different climatic conditions, ranging from temperate to tropics during most of cropping seasons and is available round the year. The word cauliflower comes from Latin term 'caulis' and 'floris', meaning stem or stalk and flower, respectively. Brassica oleracea $\mathrm{L}$. grows wild in primitive form in Atlantic coasts of Europe. All the cultivated forms of cole group are believed to be
Twenty five genotypes of cauliflower along with one check Madhuri were evaluated for yield and some yield contributing morpho-physiological components in cauliflower. The analysis of variance revealed that mean squares due to genotypes were significant for all traits highlighting the presence of sufficient genetic variability among the genotypes. The hybrids $\mathrm{H} 1$ and $\mathrm{H} 4$ were found superior for traits like days to initiation of curd from transplanting, days to marketable curd maturity from date of transplanting, curd compactness, curd solidity and harvest index and comparable in performance for marketable yield per plant, gross weight per plant and curd diameter with standard check Madhuri. On the basis of visual observation, position of leaves was categorized as Type No. 3 for all the hybrids except H 5 whereas for protection of leaves to curd majority of riceyness were observed for most of the hybrids which is ideal for selection.

descendent of Brassica oleracea var. sylvestris $L$., commonly known as wild cabbage, a leafy kale like plant through mutation, human selection and adaptation about 2000 years ago in the Eastern Mediterranean region (Boriss et al., 2006) where it became fully domesticated and started giving rise to wide range of cultivated forms. Cauliflower is comparatively of a later origin, about 500 years ago, probably by introgression within broccoli gene pool having a close genetic affinity. Syria is considered to be place of origin for cauliflower. It was first introduced in Italy around 1490 which became the centre of 
genetic diversity of cauliflower where several land races of this crop are still available even today. The herbalist Dodens, whose first work appeared in 1544, gave for the first time a picture of cauliflower with a description. Schulz (1919) suggested Brassica cretica, the probable progenitor of cauliflower. It was introduced into cultivation rather late, and before that cauliflower was only grown on a small scale. One of the reasons for this may be that cauliflower makes heavy demands on the professional skill of the growers, and its cultivation often fails under less favourable growing conditions than are normally required. In the USA, it was first mentioned in 1806 but attained commercial status after 1920.

In India, area under hybrids in cauliflower is low as compared to open pollinated and unknown varieties. Thus, for increasing its production and productivity at par with advance countries, it is essential to grow the location and environment specific best performing hybrids. The advantage of using hybrids for commercial production in cole crops including cauliflower is well documented. Hybrids have been found advantageous by having high vigor, yield, earliness, uniformity in maturity, size and shape of the curds, adaptability, resistance to some pests and diseases and good shelf life. In cauliflower, growing of commercial hybrids in contrast to other Brassica vegetables picked up late and it is only since about 1985 they attained commercial reality (Crisp and Tapsell, 1993). The reasons may be thermosensitivity of the crop and unavailability of good performing hybrids. But now almost all the cauliflower grown in the developed countries are $F_{1}$ hybrids, mainly because of economical interest and not for agronomical reasons. In India still the share of cauliflower hybrid cultivars is less than 11 percent (Muthukumar and Selvakumar, 2014) and the picture of many other developing countries is no way better than this. Indian cauliflowers especially those types belong to early maturity groups are grown under adverse climatic conditions need immediate attention of breeders to identify those hybrids which would perform best in these conditions along with the mechanisms for lowering the cost of hybrid seeds to have it within the reach of common growers. Recently the use of hybrids in India has seen a breakthrough with hybrid seed being used for many vegetables. $F_{1}$ hybrids Pusa Kartik Sankar, Pusa Hybrid-2 (early maturing) and Pusa Snowball hybrid (late maturing) developed by Indian Agricultural Research Institute have been identified for growing. Further research on $\mathrm{F}_{1}$ hybrid cultivars would also increase the use of hybrid seeds. In Himachal Pradesh to increase the production and productivity of cauliflower and elevate the income of farmers it is advisable to grow hybrids. For this it is necessary to identify the location and environment specific best performing hybrids. Based upon these considerations, the present investigation entitled, was planned and executed with the objective to evaluate and suggest the best hybrids on the basis of mean performance.

\section{Materials and Methods}

The present investigation was carried out at the Experimental Farm of the Department of Vegetable Science and Floriculture, CSK HPKV Palampur to study the performance of various hybrids and to identify the promising ones. The research farm is situated at $3206^{\prime} \mathrm{N}$ latitude and 760 3' E longitude at an elevation of $1290.8 \mathrm{~m}$ amsl. The location is characterized by humid and temperate climate with an annual rainfall of $2,500 \mathrm{~mm}$ of which $80 \%$ is received during June to September and represents the mid-hill zone of Himachal Pradesh. 25 private sector hybrids including Madhuri as standard check were evaluated in Randomized Block Design with three 
replications during rabi, season 2014-15. Data were recorded on days to curd initiation from transplanting, days to marketable curd maturity from date of transplanting, gross weight per plant, marketable yield per plant, curd depth, curd diameter, curd size index, per cent marketable curds, curd compactness, curd solidity, stalk length, number of leaves per plant, plant height, dry matter content, ascorbic acid content, total soluble solids and harvest index. The standard cultural practices to raise the healthy crop were followed as per the recommendations of package of practices for vegetable crops. The data for different characters was analyzed for variability (ANOVA) as per Gomez and Gomez (1983). The calculated ' $F$ ' value was compared with the tabulated ' $F$ ' value at 5 per cent level of significance. If the calculated ' $F$ ' value was higher than the tabulated, it was considered to be significant. The analysis was carried out using OPSTAT Software.

\section{Results and Discussion}

\section{Analysis of variance}

The analysis of variance (ANOVA) revealed that mean squares due to genotypes were highly significant for all the 17 characters studied, thereby exhibiting the presence of sufficient genetic variability in the genotypes (Table 1). Earlier workers namely, Santhosha et al., (2014) and Chittora and Singh (2015) have also reported variability in their respective cauliflower material for different set of characters studied.

\section{Mean performance of different genotypes}

\section{Earliness}

Earliness is highly desirable character in all the vegetables in the sense that the prevailing price in the market is invariably high early in the season (Singh et al., 2017). Days to initiation of curd from transplanting of different genotypes ranged from 93 days $(\mathrm{H} 1$, H 10) to 112 days (H 19) with mean of 102.47 days (Table 2). Statistical analysis of the data indicated that the hybrids $\mathrm{H} \mathrm{1,} \mathrm{H} \mathrm{6,} \mathrm{H} 10$ and $\mathrm{H} 11$ were found significantly superior and showed early curd initiation than the standard check Madhuri while H 5, H 15 and H 17 were at par with standard check. Days to marketable curd maturity from date of transplanting was recorded by counting the number of days from date of transplanting to the days curds attained marketable size and ranged from 107 days $(\mathrm{H} 6)$ to 128 days $(\mathrm{H}$ 19) with an average of 119.15 days. H 1, H 5, $\mathrm{H} 6, \mathrm{H} 10$ and $\mathrm{H} 11$ were found significantly superior and showed early curd maturity than the check Madhuri while H 7, H 15 and H 17 were at par with check. These findings are also supported by Santhosha et al., (2014) and Chittora and Singh (2015), who had also observed significant difference for days to curd initiation and days to marketable curd maturity.

\section{Yield traits}

Gross weight per plant, marketable yield per plant and per cent marketable curds are the important traits which reflects the yield potential of particular genotype. The overall mean of gross weight per plant in the genotypes was $1413.5 \mathrm{~g}$ (Table 2). It was maximum (1413.15 g) in standard check Madhuri and minimum (940.20) in $\mathrm{H} 9$. Genotypes H 1, H 4 and H 14 were at par with check Madhuri. All the remaining hybrids manifested significantly lesser gross weight per plant than the standard check. Marketable yield per plant $(\mathrm{g}$ ) was observed maximum in $\mathrm{H} 1$ (1021.78 g) and minimum in H 5 (529.31 g) with an overall mean of $759.56 \mathrm{~g}$. Among the genotypes, $\mathrm{H} \mathrm{1,} \mathrm{H} 4$ and $\mathrm{H} 14$ were at par with the standard check, whereas remaining 21 hybrids recorded significantly lesser marketable yield. The results are in agreement 
with those of Singh et al., (2013), Santhosha et al., (2014) and Chittora and Singh (2015) who had also reported considerable variation for gross weight per plant and marketable yield per plant in cauliflower genotypes.

Per cent marketable curds ranged from minimum $78.30 \%$ in $(\mathrm{H} 5)$ to maximum $100 \%$ in (H 13) with an overall mean of $84.94 \%$. Genotypes which formed significantly higher per cent of marketable curds than the standard check Madhuri were $\mathrm{H}$ 2, H 3, H 13, H 14, H 16, H 17, H 21 and H 22 whereas $\mathrm{H} \mathrm{5,H} \mathrm{11,} \mathrm{H} 19$ and $\mathrm{H} 20$ had significantly lower percent marketable curds than the check. All the remaining genotypes $\mathrm{H}$ 1, H 4, H 6, H 7, H 8, H 9, H 10, H 12, H 15, $\mathrm{H} \mathrm{18,} \mathrm{H} 23$ and $\mathrm{H} 24$ were at par with the standard check. These results collaborate the findings of Dubey et al., (2003) and Sharma et al., (2006) who had also reported significant variation for the curd size index among the different genotypes.

\section{Curd characters}

Curd depth, curd diameter, curd compactness and solidity in general reflects the quality of curd. Genotype favoring to these characters is considered ideal as per consumer preference. Analysis of variance revealed significant differences for curd depth which ranged from $6.50 \mathrm{~cm}$ in (H 5) to $9.15 \mathrm{~cm}$ in (H 22) with an average of $7.57 \mathrm{~cm}$ (Table 2). Two cultivars namely $\mathrm{H} 22$ and $\mathrm{H} 23$ surpassed significantly the standard check Madhuri. On the other hand, hybrids $\mathrm{H} \mathrm{1,} \mathrm{H} \mathrm{8,} \mathrm{H} \mathrm{13,} \mathrm{H} 14$ and $\mathrm{H} 24$ had comparable curd depth with the check variety, while rest of the genotypes exhibited significantly lesser curd depth than the standard cultivar. The average curd diameter of the population was $11.28 \mathrm{~cm}$ ranged from $10.00 \mathrm{~cm}$ in $(\mathrm{H} 3)$ to $13.51 \mathrm{~cm}$ in standard check. Two hybrids namely $\mathrm{H} 1$ and $\mathrm{H} 4$ were at par with the standard check. Rest all the hybrids exhibited lesser curd diameter in comparison to standard check. For this trait in cauliflower significant difference was also observed by Sharma et al., (2006), Santhosha et al., (2014) and Chittora and Singh (2015). The product of equatorial and polar diameter was used to work out the curd size index, which ranged from $65.65 \mathrm{~cm}^{2}$ in $(\mathrm{H} 5)$ to $117.19 \mathrm{~cm}^{2}$ in standard check Madhuri with population mean of $94.56 \mathrm{~cm}^{2}$. All the genotypes have lesser curd size index from standard check. Curd compactness is also a yield contributing character and tightly compact curds preferred in market. The average curd compactness of the population was $111.69^{\circ}$ with maximum $115.22^{0}$ in $(\mathrm{H} 1)$ and minimum $105.83^{\circ}$ in $(\mathrm{H} 8)$. There were 18 genotypes viz., $\mathrm{H} \mathrm{1,} \mathrm{H} \mathrm{2,} \mathrm{H} \mathrm{3,} \mathrm{H} \mathrm{4,} \mathrm{H} \mathrm{6,} \mathrm{H} \mathrm{7,} \mathrm{H}$ 9, H 10, H 11, H 12, H 13, H 14, H 16, H 17, $\mathrm{H} 18, \mathrm{H} \mathrm{19}, \mathrm{H} 21$ and $\mathrm{H} 23$ which were at par with the standard check and six genotypes namely $\mathrm{H} \mathrm{5,} \mathrm{H} \mathrm{8,} \mathrm{H} \mathrm{15,} \mathrm{H} \mathrm{20,} \mathrm{H} 22$ and $\mathrm{H} 24$ were significantly inferior in compactness to standard check. The differences for curd compactness were also reported by Kumar et al., (2011) and Sheemar et al., (2012) in their breeding material. Curd solidity was quantified by determining the ratio between curd weight $(\mathrm{g})$ and curd depth $(\mathrm{cm})$. The average curd solidity of the population was $99.04 \mathrm{~g} / \mathrm{cm}$ with maximum in $\mathrm{H} 4(125.30$ $\mathrm{g} / \mathrm{cm})$ and minimum in $\mathrm{H} 24(66.78 \mathrm{~g} / \mathrm{cm}) .11$ hybrids namely $\mathrm{H} \mathrm{1,} \mathrm{H} \mathrm{2,} \mathrm{H} \mathrm{4,} \mathrm{H} \mathrm{6,} \mathrm{H} \mathrm{7,} \mathrm{H} \mathrm{9,}$ $\mathrm{H} 10, \mathrm{H} \mathrm{11,} \mathrm{H} \mathrm{12,} \mathrm{H} 14$ and $\mathrm{H} 18$ were at par with the standard check.

\section{Morphological traits}

Data were recorded on three morphological traits namely, stalk length, number of leaves per plant and plant height. The shorter stem length is preferred for cultivation as it can withhold higher curd weight. However some genotypes have recorded longer stalk length which may be suitable for mechanical harvesting which is not practiced in our country. 
Table.2 Mean values of twenty five cauliflower hybrids for the characters studied

\begin{tabular}{|c|c|c|c|c|c|c|c|c|c|c|c|c|c|c|c|c|c|}
\hline Hybrids & $\begin{array}{l}\text { Days to } \\
\text { initiation of } \\
\text { curd from } \\
\text { transplanting }\end{array}$ & $\begin{array}{c}\text { Days to } \\
\text { marketable } \\
\text { curd } \\
\text { maturity } \\
\text { from date of } \\
\text { transplanting }\end{array}$ & $\begin{array}{l}\text { Gross } \\
\text { weight } \\
\text { per } \\
\text { plant } \\
\text { (g) }\end{array}$ & $\begin{array}{l}\text { Market } \\
\text { yield } \\
\text { per } \\
\text { plant } \\
\text { (g) }\end{array}$ & $\begin{array}{l}\text { Curd } \\
\text { depth } \\
(\mathrm{cm})\end{array}$ & $\begin{array}{l}\text { Curd } \\
\text { diameter } \\
(\mathrm{cm})\end{array}$ & $\begin{array}{l}\text { Curd } \\
\text { size } \\
\text { index } \\
\left(\mathrm{cm}^{2}\right)\end{array}$ & $\begin{array}{c}\text { Curd } \\
\text { compac } \\
\text { tness } \\
\left.0^{0}\right)\end{array}$ & $\begin{array}{l}\text { Curd } \\
\text { solidity } \\
(\mathrm{g} / \mathrm{cm})\end{array}$ & $\begin{array}{c}\% \\
\text { Market } \\
\text { able } \\
\text { curds }\end{array}$ & $\begin{array}{c}\text { Stalk } \\
\text { length } \\
(\mathrm{cm})\end{array}$ & $\begin{array}{c}\text { Number } \\
\text { of } \\
\text { leaves } \\
\text { per } \\
\text { plant }\end{array}$ & $\begin{array}{c}\text { Plant } \\
\text { height } \\
(\mathrm{cm})\end{array}$ & $\begin{array}{c}\text { Dry } \\
\text { matter } \\
\text { content } \\
(\%)\end{array}$ & $\begin{array}{l}\text { Ascorbic } \\
\text { acid } \\
\text { content } \\
\text { (mg/100g) }\end{array}$ & $\begin{array}{c}\text { Total } \\
\text { soluble } \\
\text { solids } \\
(0 \\
\text { Brix) }\end{array}$ & $\begin{array}{c}\text { Harvest } \\
\text { index } \\
(\%)\end{array}$ \\
\hline H 1 & 93.00 & 111.00 & 1366.00 & 1021.78 & 8.36 & 13.05 & 109.25 & 115.22 & 122.22 & 96.6 & 4.78 & 12.33 & 44.3 & 8.33 & 58.87 & 6.67 & 74.80 \\
\hline H 2 & 108.00 & 124.00 & 1249.00 & 810.78 & 7.92 & 10.60 & 83.95 & 113.87 & 102.89 & 97.9 & 4.10 & 12.33 & 44.2 & 9.50 & 49.13 & 6.77 & 64.91 \\
\hline H 3 & 103.00 & 122.00 & 1088.78 & 722.22 & 7.75 & 10.00 & 77.00 & 113.13 & 93.16 & 98.0 & 3.73 & 13.00 & 44.8 & 9.33 & 55.08 & 6.70 & 66.33 \\
\hline H 4 & 104.33 & 124.00 & 1389.33 & 978.67 & 7.81 & 12.83 & 100.20 & 110.91 & 125.30 & 96.1 & 3.90 & 13.00 & 43.1 & 10.00 & 60.29 & 6.67 & 70.44 \\
\hline H 5 & 97.00 & 111.33 & 1322.15 & 529.31 & 6.50 & 10.10 & 65.65 & 107.45 & 81.43 & 78.3 & 3.93 & 12.67 & 44.6 & 6.67 & 41.33 & 5.63 & 47.25 \\
\hline$\overline{\text { H } 6}$ & 95.33 & 107.33 & 1120.00 & 863.77 & 7.09 & 12.50 & 88.62 & 114.02 & 121.83 & 95.9 & 3.03 & 11.00 & 46.6 & 10.17 & 67.13 & 5.53 & 65.33 \\
\hline H 7 & 100.00 & 117.00 & 1156.67 & 844.17 & 7.60 & 11.36 & 86.37 & 115.09 & 111.08 & 94.7 & 3.07 & 12.00 & 39.9 & 10.33 & 35.00 & 6.20 & 63.81 \\
\hline H 8 & 105.00 & 120.00 & 1242.50 & 731.67 & 8.57 & 10.23 & 87.67 & 105.83 & 85.37 & 93.0 & 3.20 & 12.33 & 47.7 & 8.67 & 42.54 & 6.23 & 58.89 \\
\hline H 9 & 107.00 & 121.00 & 940.20 & 760.93 & 7.37 & 11.40 & 84.08 & 111.46 & 103.25 & 95.0 & 3.71 & 12.67 & 45.8 & 9.67 & 39.62 & 5.43 & 80.93 \\
\hline H 10 & 93.00 & 110.00 & 1205.00 & 752.57 & 7.50 & 11.52 & 87.20 & 114.42 & 99.41 & 94.0 & 2.67 & 13.33 & 39.3 & 8.00 & 43.67 & 6.60 & 62.05 \\
\hline H 11 & 95.33 & 112.00 & 1153.89 & 761.23 & 7.42 & 11.50 & 85.33 & 112.27 & 102.59 & 88.6 & 3.28 & 13.33 & 43.8 & 9.00 & 48.64 & 6.70 & 65.97 \\
\hline H 12 & 103.33 & 120.00 & 1121.48 & 749.26 & 7.66 & 11.34 & 86.86 & 112.51 & 97.81 & 96.7 & 3.10 & 12.00 & 45.1 & 8.00 & 48.47 & 6.60 & 66.11 \\
\hline H 13 & 103.00 & 122.67 & 1307.33 & 777.76 & 8.71 & 11.36 & 98.95 & 113.10 & 89.30 & 100.0 & 2.70 & 12.00 & 43.8 & 8.67 & 46.67 & 5.87 & 59.49 \\
\hline H 14 & 102.00 & 121.00 & 1408.75 & 975.33 & 8.25 & 12.28 & 101.31 & 114.57 & 118.22 & 97.3 & 3.63 & 12.33 & 44.3 & 7.00 & 49.42 & 6.63 & 69.33 \\
\hline H 15 & 98.00 & 114.00 & 1195.00 & 632.33 & 6.70 & 10.75 & 72.56 & 106.14 & 94.33 & 94.5 & 2.73 & 10.67 & 46.0 & 9.67 & 67.25 & 6.60 & 52.91 \\
\hline H 16 & 111.00 & 125.33 & 1029.67 & 574.50 & 6.53 & 10.84 & 70.79 & 112.95 & 87.98 & 98.0 & 3.10 & 10.67 & 45.1 & 8.33 & 54.61 & 6.63 & 55.79 \\
\hline H 17 & 98.00 & 115.00 & 1227.67 & 675.35 & 7.17 & 10.68 & 76.58 & 111.77 & 94.19 & 98.2 & 3.01 & 11.67 & 42.9 & 10.00 & 39.94 & 7.30 & 55.01 \\
\hline H 18 & 111.00 & 126.00 & 1017.87 & 710.23 & 6.51 & 11.26 & 73.30 & 114.82 & 109.10 & 95.1 & 3.28 & 11.00 & 43.2 & 10.00 & 51.75 & 7.40 & 69.78 \\
\hline H 19 & 112.00 & 128.00 & 1063.00 & 642.31 & 7.02 & 10.15 & 71.25 & 110.29 & 91.50 & 87.0 & 2.88 & 12.33 & 44.1 & 9.00 & 51.93 & 6.40 & 60.42 \\
\hline H 20 & 103.67 & 122.00 & 1087.50 & 660.61 & 7.09 & 10.75 & 76.22 & 107.47 & 93.17 & 91.2 & 3.17 & 11.67 & 45.1 & 8.33 & 46.00 & 6.30 & 60.74 \\
\hline H 21 & 108.00 & 125.00 & 1180.00 & 698.04 & 7.41 & 10.53 & 78.02 & 113.10 & 94.20 & 97.3 & 3.53 & 13.00 & 43.1 & 10.33 & 42.67 & 7.07 & 59.16 \\
\hline H 22 & 101.00 & 124.33 & 1102.50 & 831.56 & 9.15 & 11.75 & 107.51 & 108.83 & 90.88 & 97.5 & 3.37 & 12.33 & 36.4 & 10.67 & 50.43 & 5.73 & 75.42 \\
\hline H 23 & 101.00 & 120.00 & 1242.60 & 717.50 & 8.83 & 11.72 & 103.48 & 110.88 & 81.26 & 93.8 & 3.45 & 11.00 & 43.6 & 9.33 & 51.33 & 6.83 & 57.74 \\
\hline H 24 & 111.67 & 120.67 & 944.76 & 565.62 & 8.47 & 10.30 & 87.22 & 108.43 & 66.78 & 94.8 & 3.23 & 11.33 & 45.7 & 9.00 & 49.24 & 6.53 & 59.87 \\
\hline $\begin{array}{l}\text { Madhuri } \\
\text { (Check) }\end{array}$ & 97.00 & 115.00 & 1413.15 & 1011.41 & 8.50 & 13.27 & 112.80 & 113.80 & 118.94 & 94.6 & 3.46 & 13.00 & 43.7 & 9.00 & 61.55 & 6.48 & 71.57 \\
\hline Mean & 102.47 & 119.15 & 1182.99 & 759.56 & 7.68 & 11.28 & 86.88 & 111.69 & 99.04 & 84.94 & 3.85 & 12.12 & 43.84 & 9.08 & 50.10 & 6.46 & 63.76 \\
\hline $\mathrm{CV}(\%)$ & 2.87 & 3.08 & 6.06 & 7.08 & 1.95 & 2.63 & 1.90 & 4.77 & 16.24 & 1.38 & 3.85 & 7.46 & 5.65 & 11.00 & 1.74 & 3.51 & 2.32 \\
\hline $\mathrm{SE}(\mathrm{m}) \pm$ & 0.46 & 0.66 & 3.22 & 2.81 & 0.22 & 0.32 & 0.73 & 0.63 & 2.19 & 0.66 & 0.22 & 0.55 & 0.59 & 0.58 & 0.54 & 0.27 & 0.65 \\
\hline $\begin{array}{c}\text { CD at } \\
\mathrm{p} \leq 0.05\end{array}$ & 1.04 & 2.11 & 51.18 & 39.01 & 0.24 & 0.52 & 2.64 & 3.93 & 23.59 & 2.15 & 0.21 & 1.48 & 1.74 & 1.64 & 1.43 & 0.37 & 2.07 \\
\hline
\end{tabular}


Table.1 Analysis of variance for randomized block design with respect to marketable yield per plant and other traits in cauliflower hybrids

\begin{tabular}{|c|c|c|c|c|}
\hline \multicolumn{5}{|c|}{ Mean squares due to } \\
\hline Sources of variation & & Replications & Genotypes & Error \\
\hline Traits & df & 2 & 24 & 48 \\
\hline Days to initiation of curd from transplanting & & 19.36 & $100.86^{* *}$ & 0.40 \\
\hline Days to marketable curd maturity from date of transplanting & & 32.21 & $97.83 * *$ & 1.66 \\
\hline Gross weight per plant (g) & & 11799.84 & $45477.00 * *$ & 972.34 \\
\hline Marketable yield per plant (g) & & 1258.56 & $33255.67 * *$ & 565.14 \\
\hline Curd depth (cm) & & 0.11 & $1.40 * *$ & 0.02 \\
\hline Curd diameter $(\mathrm{cm})$ & & 0.07 & $2.40 * *$ & 0.10 \\
\hline Curd size index $\left(\mathrm{cm}^{2}\right)$ & & 1.37 & $455.70 * *$ & 2.58 \\
\hline Curd compactness $\left({ }^{0}\right)$ & & 7.91 & $21.22 * *$ & 17.82 \\
\hline Curd solidity (g/cm) & & 72.07 & $1223.75^{* *}$ & 206.56 \\
\hline \% Marketable curds & & 1.49 & $60.80 * *$ & 1.71 \\
\hline Stalk length $(\mathrm{cm})$ & & 0.01 & $0.71 * *$ & 0.02 \\
\hline Number of leaves per plant & & 3.36 & $2.00 * *$ & 0.82 \\
\hline Plant height (cm) & & 9.82 & $17.00 * *$ & 1.12 \\
\hline Dry matter content (\%) & & 1.72 & $3.11 * *$ & 1.00 \\
\hline Ascorbic acid content (mg/100g) & & 18.66 & $207.01 * *$ & 0.76 \\
\hline Total soluble solids ( ${ }^{0}$ Brix) & & 0.81 & $0.77 * *$ & 0.05 \\
\hline Harvest index (\%) & & 1.50 & $169.91 * *$ & 1.60 \\
\hline
\end{tabular}

Table.3 Visual observation of hybrids

\begin{tabular}{|l|l|}
\hline Traits \\
\hline Hybrids \\
\hline H 1 \\
\hline H 2 \\
\hline H 3 \\
\hline H 4 \\
\hline H 5 \\
\hline H 6 \\
\hline H 7 \\
\hline H 8 \\
\hline H 9 \\
\hline H 10 \\
\hline H 11 \\
\hline H 12 \\
\hline H 13 \\
\hline H 14 \\
\hline H 15 \\
\hline H 16 \\
\hline H 17 \\
\hline H 18 \\
\hline H 19 \\
\hline H 20 \\
\hline H 21 \\
\hline H 22 \\
\hline H 23 \\
\hline H 24 \\
\hline Madhuri \\
\hline (Check) \\
\hline In- incurving S-in \\
\hline
\end{tabular}

\begin{tabular}{|c|c|}
\hline Position of leaves & Protection of leaves \\
\hline & \\
\hline Type-3 & E \\
\hline Type-3 & E \\
\hline Type-3 & E \\
\hline Type-3 & S-in \\
\hline Type-2 & S-in \\
\hline Type-3 & E \\
\hline Type-3 & S-in \\
\hline Type-3 & In \\
\hline Type-3 & S-in \\
\hline Type-3 3 S-in \\
\hline Type-3 & S-in \\
\hline Type-3 3 & In \\
\hline Type-3 & S-in \\
\hline Type-3 3 & S-in \\
\hline Type-3 & S-in \\
\hline Type-3 3 & S-in \\
\hline Type-3 & S-in \\
\hline Type-3 3 & In \\
\hline Type-3 & In \\
\hline Type-3 & In \\
\hline Type-3 & S-in \\
\hline Type-3 & S-in \\
\hline Type-3 & In \\
\hline Type-3 3 Type-3 & S-in \\
\hline & S-in \\
\hline & \\
\hline
\end{tabular}

\begin{tabular}{|c|c|}
\hline \multicolumn{2}{|c|}{ Curd qualities } \\
\hline Colour & Riceyness \\
\hline & N \\
\hline W & Non-ricey \\
\hline SW & Non-ricey \\
\hline W & Non-ricey \\
\hline W & Ricey \\
\hline W & Non-Ricey \\
\hline W & Non-ricey \\
\hline W & Non-ricey \\
\hline W & Non-ricey \\
\hline SW & Non-ricey \\
\hline SW & Non-ricey \\
\hline W & Non-ricey \\
\hline W & Non-ricey \\
\hline W & Non-ricey \\
\hline W & Non-ricey \\
\hline W & Non-ricey \\
\hline W & Non-ricey \\
\hline W & Non-ricey \\
\hline W & Non-ricey \\
\hline W & Non-ricey \\
\hline W & Non-ricey \\
\hline SW & Non-ricey \\
\hline W & Non-ricey \\
\hline W & Non-ricey \\
\hline W & Non-ricey \\
\hline & \\
\hline
\end{tabular}

In- incurving, S-in- semi incurving and E- erect, SW-snow white, W- white 
The variation in performance for stalk length ranged from minimum $2.67 \mathrm{~cm}$ in $(\mathrm{H} \mathrm{10})$ to maximum $4.78 \mathrm{~cm}$ in $(\mathrm{H} 1)$ with an overall mean of $3.85 \mathrm{~cm}$ (Table 2). 12 genotypes viz., H 6, H 7, H 8, H 10, H 12, H 13, H 15, H16, $\mathrm{H} 17, \mathrm{H} 19, \mathrm{H} 20$ and $\mathrm{H} 24$ had significantly shorter stalk length than the standard check. Six genotypes namely, $\mathrm{H} 11, \mathrm{H} 14, \mathrm{H} \mathrm{18}, \mathrm{H}$ 21, H 22 and H 23 had comparable stalk length as that of standard check Madhuri. Number of leaves per plant is an important character contributing towards increased photosynthesis thereby resulting in increased curd weight. The genotypes under study revealed substantial variability as indicated by the significant analysis of variance for number of leaves per plant which ranged from 10.67 in $(\mathrm{H} \mathrm{15})$ to 13.33 in $(\mathrm{H} \mathrm{10)}$ with an average of 12.12 . 18 cultivars viz., $\mathrm{H} 1, \mathrm{H} 2$, $\mathrm{H} \mathrm{3,} \mathrm{H} \mathrm{4,} \mathrm{H} \mathrm{5,} \mathrm{H} \mathrm{7,} \mathrm{H} \mathrm{8,} \mathrm{H} \mathrm{9,} \mathrm{H} \mathrm{10,} \mathrm{H} \mathrm{11,} \mathrm{H}$ 12, H 13, H 14, H 17, H 19, H 20, H 21 and H 22 had statistically same number of leaves as that of standard check Madhuri. No genotype had more leaves number than the standard check. Plant height of different genotypes ranged from $36.40 \mathrm{~cm}$ in (H 22) to $47.70 \mathrm{~cm}$ in (H 8) with an overall mean of $43.84 \mathrm{~cm}$. Four hybrids namely $\mathrm{H} 6, \mathrm{H} 8$ and $\mathrm{H} 15$ and H 24 were found significantly better for plant height than standard check whereas three hybrids viz., H 7, H 10 and $\mathrm{H} 22$ had shorter plant height than standard check and rest of the hybrids were at par with the standard check Madhuri. Santhosha et al., (2014) and Chittora and Singh (2015) also depicted significant differences for these morphological traits.

\section{Quality Traits}

For quality, genotypes were evaluated for harvest index, dry matter content, Ascorbic acid, total soluble solids, curd colour and their behaviour towards physiological disorders. The highest harvest index of 80.93 per cent was recorded in $\mathrm{H} 9$ and lowest 47.25 per cent was observed in $\mathrm{H} 5$ with an overall mean of 63.76 per cent (Table 2). Significantly higher harvest than Standard check was observed in $\mathrm{H} 1, \mathrm{H} 9$ and $\mathrm{H} 22$ whereas $\mathrm{H} 4$ and $\mathrm{H} 18$ were at par with the check. Remaining all hybrids recorded significantly lesser harvest index than the check. A wide variation for harvest index in the breeding material was also observed by Nimkar and Korla (2014), Santhosha et al., (2014) and Chittora and Singh (2015). Dry matter content ranged from minimum 6.67 per cent in $\mathrm{H} 5$ and 10.67 per cent in $\mathrm{H} 22$ with overall mean of 9.08 per cent. H 22 had the highest percent of dry matter content as compared to check whereas hybrids $\mathrm{H} 5$ and $\mathrm{H} 14$ has lowest percent of dry matter content and rest all the hybrids were at par with the standard check Madhuri. Highest ascorbic acid was reported in $\mathrm{H} 15$ (67.25mg) and lowest in $\mathrm{H} 7(35.00 \mathrm{mg})$ with an overall mean of $50.10 \mathrm{mg} / 100 \mathrm{~g}$. Two genotypes namely $\mathrm{H} \quad 6$ and $\mathrm{H} 15$ had significantly high ascorbic acid content whereas hybrid $\mathrm{H} 4$ was at par with the standard check Madhuri. Rest all the genotypes showed significantly less content of ascorbic acid in comparison with the check. Sheemar et al., (2012) and Yadav et al., (2013) have reported variation for dry matter content and ascorbic acid in their respective breeding material. The overall mean of total soluble solids in the genotypes was $6.46{ }^{0}$ Brix. It ranged from minimum 5.43 in (H 9) to maximum 7.40 in $(\mathrm{H} \mathrm{18)}$. For this trait three genotypes namely $\mathrm{H} 17, \mathrm{H} 18$ and H 21 significantly surpassed the standard check Madhuri, whereas five hybrids $\mathrm{H} 5, \mathrm{H}$ 6, H 9, H 13 and H 22 exhibited significantly less TSS and remaining all the hybrids were at par with the standard check. With respect to curd colour and riceyness, curd quality is important to discuss. Most of the hybrids had white curds except where the curd colour was snow white. Out of 25 hybrids, four hybrids $\mathrm{H}$ 3, $\mathrm{H} \mathrm{10,} \mathrm{H} 11$ and $\mathrm{H} 22$ are snow white in colour and rest of the hybrids showed white 
coloured curds. Ricyness is a polygenic character and much influenced by the environment. All the curds of hybrids were free from ricyness except one hybrid i.e. H 5 exhibited ricey curds.

\section{Visual observations}

Hybrids were observed for two morphological characters namely, position of leaves and protection of leaves to curds, and results are presented in Table 3. The position of the leaves was determined in relation to curd at maturity. The leaves of all the hybrids were categorised as Type No. 3 of plant type in cauliflower i.e. erect leaves. Type No. 3 is ideal for selection as in this case the leaves almost cover the curd unlike the Type No. 1, in which the curd is completely exposed. Type No. 4 (very erect) is not desirable because in such plants the curd is very small and unmarketable and one hybrid named $\mathrm{H} 5$ showed Type No. 2 i.e. semi erect leaves. By visually observing the plants for leaf coverings, they were categorised as incurving, semi incurving and erect leaves. Majority of the hybrids had semi-incurving leaves except for four hybrids i.e. $\mathrm{H} \mathrm{1,} \mathrm{H} \mathrm{2,} \mathrm{H} 3$ and $\mathrm{H} 6$ which showed erect leaves and six hybrids namely $\mathrm{H}$ 8, H 12, H 18, H 19, H 20 and $\mathrm{H} 23$ had incurving leaves.

\section{References}

Boriss, H., Brunkle, H., and Kreith, M. 2006. Commodity Profile: Cauliflower, Agricultural Issues Centre, University of California.

Chittora, A., and Singh, D.K. 2015. Genetic variability study in early cauliflower (Brassica oleracea L. var. botrytis). Electron. J. Plant Breed., 6: 842-847.

Crisp, P., and Tapsell, C.R. 1993. Cauliflower (Brassica oleracea L. var. botrytis). In: Kalloo G and Bergh (BO) (eds.), Genetic Improvement of Vegetable
Crops. Pergamon Press. Oxford, pp.157-178.

Dubey, R.K., Singh, B.P., and Ram, H.H. 2003. Genetic variability, heritability and genetic advance for quantitative characters in Indian cauliflower (Brassica oleracea L. var. botrytis). Veg. Sci., 30: 81-82.

Gomez, K.A., and Gomez, A.A. 1983. Statistical procedure for agricultural research. 2nd Ed. John Wiley and Sons, New York, p 357-427.

Kumar, M., Sharma, S.R., Kalia, P., and Saha, P. 2011. Genetic variability and character association for yield and quality traits in early maturing Indian cauliflowers. Indian J. Horti., 68: 206211.

Muthukumar, P., and Selvakumar, R. 2014. Seed Production in Vegetable Crops. Glaustas Horticulture pp 335.

Nimkar., S.A., and Korla, B.N. 2014. Studies on comparison of biparental and $\mathrm{F}_{4}$ progenies in late cauliflower (Brassica oleracea L. var. botrytis). Int. J. Farm Sci., 4: 27-34.

Santhosha, H.M., Varalakshmi, B., and Shivashankara, K.S. 2014. Characterization of early cauliflower germplasm under tropical conditions. The Bioscan., 9: 869-874.

Schulz, O.C. 1919. Das pflanzenreich Ed. A. Engler Leipzig 4. 1-290.

Sharma, A., Sharma, S., Pathak, S., and Sood, S. 2006. Genetic variability for curd yield and its component traits in cauliflower (Brassica oleracea L. var. botrytis) under high hills dry temperate conditions. Veg. Sci., 33: 82-84.

Sheemar, G., Singh, D., Malik, A. and Kumar, A. 2012. Correlation and Path analysis studies of economic traits in cauliflower (Brassica oleracea L. var. botrytis). J. Agricul. Tech., 85: 17911799.

Singh, P., Kumar, S., Maji, S. and Singh, A. 
2013. Genetic variability, heritability and genetic advance in cauliflower (Brassica oleraceae L. var. botrytis). Int. J. Plant Sci., 8: 179-182.

Singh, Y., Sharma, S., Sekhon, B.S., Verma, A., and Sharma, S. 2017. Performance of Broad Bean (Vicia faba L.) Genotypes for Pod Yield and Yield Contributing Morpho-physiological
Components under Mid Hill Conditions of North Western Himalayas. Biotechnol. J. Int., 19(3): 1-10.

Yadav, M., Prasad, V.M. and Ahirwar, C.S. 2013. Varietal evaluation of cauliflower (Brassica oleracea L. var. botrytis) in Allahabad agro - climatic condition. Trends in Biosci., 6: 99-100.

\section{How to cite this article:}

Surbhi Sharma, Yudhvir Singh, Simran Sharma, Vishalakshi and Bhallan Singh Sekhon. 2018. Studies on Mean Performance for Yield and its Contributing Traits in Cauliflower (Brassica oleracea L. var. botrytis L.) Under Mid Hill Conditions of North-Western Himalayas. Int.J.Curr.Microbiol.App.Sci. 7(02): 3288-3296. doi: https://doi.org/10.20546/ijcmas.2018.702.395 